УДК 930.23:94(47).031

DOI: $10.22378 / 2313-6197.2021-9-4.857-877$

\title{
THE CRIMEA QUESTION IN "WESTERN” PROJECTS, POLITICAL TREATISES, AND CORRESPONDENCE FROM THE MID-SIXTEENTH CENTURY TO 1783
}

\author{
N.I. Khrapunov \\ V.I. Vernadsky Crimean Federal University \\ Simferopol, Russian Federation \\ khrapunovn@mail.ru
}

\begin{abstract}
Research objective: This paper aims at the revealing and analysing various documents, created in different countries of Europe prior to 1783, which suggested the change of the Crimea's status and its accession to Russia, and the determination of interactions of these sources and general trends and principles behind discussions of the "Crimea question" in Russian and foreign public opinion.

Research materials: This research addresses a large body of sources, created in Russia and the West from the sixteenth to eighteenth century, discussing the future of the Crimea political treatises, memoranda, historical works, and correspondence.

Research novelty and results: For the first time in the scholarship, the whole array of available sources on the planned accession of the Crimea to Russia has been analysed. It has been discovered that there were periods when the "Crimea question" was disputed in the West far more widely than in Russia. This "discussion" continued with the participation of very different authors, including the leading minds of the public discourse such as Voltaire or Francesco Algarotti. The attempts of the western intellectuals to influence the Russian government's decisions have been demonstrated. Therefore, the accession of the Crimea is a product of not only "Russian imperialism", as it is often suggested, but to a certain extent also of the Western Europe's public mindset. Obviously, such a development was considered quite admissible in the West, and many authors viewed it positively both for international relations and for the internal perspectives of the region. The given article has exposed the dynamics in these arguments, with initial counter-Muslim rhetoric underlining the existential opposition of Christianity and Islam and the need for "returning" lands which had formerly belonged to Europe. When the Enlightenment era started, the further reason of Europe's civilizing mission appeared. This mission was thought to be impeded in the Black Sea by the "backward" Islamic society. In Russia, the discussion of the future of the Crimea became topical in the second and third quarter of the eighteenth century, probably when the elite realized that the conquest of the peninsula had now become a reality.
\end{abstract}

Keywords: Crimea, Russia, Crimean Khanate, Ottoman Empire, public thought, projects

For citation: Khrapunov N.I. The Crimea Question in "Western" Projects, Political Treatises, and Correspondence from the mid-sixteenth century to 1783. Zolotoordynskoe obozrenie $=$ Golden Horde Review. 2021, vol. 9, no. 4, pp. 857-877. DOI: 10.22378/23136197.2021-9-4.857-877

Acknowledgements: This work was carried out within the framework of the state assignment No. FZEG-2020-0029 supported by the Ministry of Science and Higher Education of the Russian Federation. 
The possibility of the Crimea's accession to Russia was discussed long before 1783. The scholarship uses to mention only the most famous projects of the kind [41, p. 66-67], like Juraj Križanić's treatise addressed to Russian Czar Alexis I [see for example: 13 , p. $21 ; 22$, p. 21-22; 62, p. 313-314], or Russian diplomatic attempt during the Russo-Ottoman wars of 1710-1713 [9, p. 87, 317-318], 1735-1739 [45, p. 188, 201, 207, 210, 212, 219], 1768-1774 and after [17, p. 510-538; 24, p. 79-82, 297-298; 26, p. 19-20, 29-30, 41-42]. However, the whole array of available sources has never been studied before in its entirety. Moreover, researchers lose sight of discussions on the Crimea's future in the countries located to the west of Russia or by the intellectuals of occidental origin. This article aims at the analysis of the whole complex of projects of the accession of the Crimea to Russia made by "western" politicians and intellectuals and determination of their possible interrelations. Here "western" refers to Russia and Europe as a cultural-historical opposition to the "eastern" world of Islam. Although Bakhchisaray actually lies to the south of Berlin, Warsaw, or Moscow, it usually happens that mental maps do not coincide with physical geography. The projects on the future of the peninsula developed in the Crimean Khanate and Ottoman Empire, i. e. on the "east", are set aside: they could become subject for specific research project. Although the relations between Moscow/St. Petersburg and Bakhchisaray regularly resulted in military conflict, this article addresses only the plans of the changes of the political status of the Crimea and not its weakening by war. Finally, the reality of these plans is not to be discussed: important for this paper is the fact of their appearance.

The first to put up the idea of the conquest of the Crimea was Prince Andrey Kurbsky (Andrei Kurbskii, 1528-1583), a courtier of Czar John IV the Terrible (15301584, reigned from 1533), when he escaped to Rzeczpospolita and published a polemic History of the Grand Prince of Moscow accusing the Czar of different crimes. This book was written in the 1570 s, ca 20 years after the events discussed in the passage on the Crimea under study. Kurbsky charged the Czar that, after the annexation of the Kazan (1552) and Astrakhan (1556) Khanates, he did not destroy the Crimean Khanate. According to the writer, "some of the advisors, brave and courageous persons", he himself in particular, talked about that plan before the Czar. Kurbsky viewed the conquest of the Crimea as the Czar's duty as a Christian and an executor of God's will: "there is need to destroy our eternal enemies, who are drinking Christian blood, and to save a multitude of captives from the old-established slavery as from the abyss of Hell". But, the writer concluded, "then our Czar carried little of that" [33, p. 98-99]. The scholarship debates if these plans were real, and whether the true intention of Moscow was to annex the Khanate or to make it independent of the Ottoman Empire. Perhaps the talks of the war on the south really happened among the Moscow elite [21, p. 281-286].

It is worth mentioning that, for almost a hundred years by the moment, Orthodox intellectuals of the Balkan origin and emissaries of the Roman Pope tried to incline Russian Czars to start war against the Ottomans with the aim of conquest of Constantinople [67, p. 85-92]. The Crimea was not mentioned in this rhetoric: only the general direction of expansion to the south and the Balkans was set. The question is if this discourse influenced Kurbsky. However, Ivan IV confined himself to some measures aimed to weaken the Crimean Khanate rather than to destroy it. In 1558, he provided assistance to the Starosta of Cherkasy and Kanev Dymitr Wiśniowiecki (Dmitrii Vishnevetskii, ?-1563), who came over to his service and waged war on the Crimeans on the Dnieper. In the next year, the Czar organized a raid against the Crimea by Voivode Daniil Adashev (?-1561), who successfully plundered a part of the country and liberated a certain number of Christian captives. In that period, the conquest and 
above all, keeping control of the Crimea were actually impossible. Apart from the Khanate's military forces, the steppe separating Muscovy from the Crimea was passable by small mobile troops of Tatar riders and not by grand Russian army of the sixteenth century, and supplies of provisions, equipment, and new people would become an unrealizable task [63, book 3, p. 493-497].

Later on, under Czar Fyodor I (1557-1598, reigned from 1584), Moscow tried to solve the "Crimean problem" by putting on the Bakhchisaray throne a loyal prince from the ruling dynasty of the Gireys who would recognize himself a vassal of the Russian Czar. In 1586, this role was given to Murad-Girey (?-1591), who fled from the Crimea in result of a dynastic conflict and got Astrakhan to rule there from the czar. Thence he was aimed to conquer the Crimea and become its ruler dependent from Russia [57, p. 134]. However, this plan did not bring any result.

Demonstrative are the materials of the embassy from Czar Boris I Godunov (1551-1605, reigned from 1598), headed by Afanasii Vlas'ev (?-after 1610), which in 1599 negotiated with the Holy Roman Emperor Rudolf II (1552-1612, reigned from 1576) and Austrian Erzherzog Maximilian (1558-1618) about a counter-Ottoman alliance with possible participation of the Polish king. The rhetoric of this negotiation followed the style of a holy war against Islam. They discussed the returning of the countries which formerly belonged to the Greek Czardom (=Byzantine Empire) and other Christian realms. Particularly, they mentioned that among the places "where Christian religion existed from ancient times, [there] had been the town of Korsun [=Cherson, Chersonese], and there the Muslim law settled, and now the Crimean state is" [51, vol. 2, col. 692]. Russia was ready to start a campaign against the Crimea "to bring freedom to Orthodox Christianity from the Muhammadan captivity and to make impediment to the Turkish [sultan], and to ravage the Crimean [khan] and to separate him from [the Sultan]..." [51, vol. 2, col. 694; cf. cols. 695, 745]. It was the time when Moscow's plans did not go farther than the liquidation of the Ottoman protectorate on the Crimea and the making of an independent polity of the latter.

The role of the Crimea in Russian foreign policies during the Time of Troubles is much discussed by the scholarship. Previously, it was considered that Pseudo-Demetrius (1582?-1606, reigned from 1605) provoked a conflict with the Crimea and prepared the conquest of the peninsula. However, now there appeared convincing arguments based on archival documents that the Russian ruler kept peaceful relations with the Khanate, and his plans concerned the conquest of the Ottoman castle of Azov located outside the Crimea, at strategical place where the Don inflowed the Azov Sea [37, p. 423].

In 1634-1635, a Russian embassy visited the Crimean Khanate. Among its participants was a priest Yakov by name. He wrote down the Tale of the relics of a saint whose name remained obscure: he was venerated in the ruins of mediaeval castle of Inkerman on the south-west of the Crimea. The priest visited that place and decided to take the relics with him to Rus' (=Muscovy). However, when he was dreaming at night, he had a vision of the saint prohibiting him doing this, "because I still want to make Rus' here" [60, p. 690, col. 2]. Yakov's memoir was addressed to Czar Mikhail I (1596-1645, reigned from 1613). It might well be not an empty talk or a religious desire, but a reflection of some plan discussed in Moscow and aimed at the accession of the Crimea.

Be that as it may, the Moscow rulers understood that they were not able to establish stable control over the northern Black Sea area primarily due to logistic reasons. Therefore, they decided not to annex Azov when it was taken by the Don Cossacks in 16371642. Researches have suggested convincing arguments that, in spite of natural counter- 
Crimea and counter-Tatar feelings raised by permanent Tatar invasions, Russia did not have plans of southern expansion in that time. Her aim was building of forts and defensive lines to protect her own lands [49, p. 507-508]. However, alternative arguments appeared among the authors of occidental origin.

In 1645, Grand Crown Hetman of Poland Stanisław Koniecpolski (1591-1646) presented to King Władysław IV (1595-1648) the Discourse on the Destruction of the Crimean Tatars and the Alliance with Moscow. It was a project of the conquest of the Crimea, expulsion of the Tatars, and transferring the peninsula to Moscow for it would establish there colonies, i. e. Christian settlements. The aim was securing the PolishRussian alliance and liquidation of the Tatar threat to Rzeczpospolita. Koniecpolski reckoned that, in contrast to Poland, Moscow was able to keep control of the Crimea. A spy was sent to the peninsula with the task of taking plans of Crimean towns and forts. However, the Hetman's death which followed in a year did not allow realization of this ambitious program [56, p. 301-304; 32, p. 5, 31-34]. It is not quite understandable if it was purely original or the Hetman was inspired by Kurbsky's reflections. At any rate, the document's rhetoric when it suggests to turn the Crimea into a Christian country and to expel "pagans" resembles the predecessor's reasoning.

The next episode is related to the name of the learned Croatian Juraj Križanić (ca 1618-1683), educated in Italy and being in close relation to Catholic circles, who spent much time in travels and finally took service with Czar Alexis I (1629-1676, reigned from 1645). He stayed in Moscow for a little more than a year and then was exiled to Tobolsk in western Siberia. There he wrote the treatise entitled Discourses on Power (or Politics, 1663) and addressed to the Czar, where he, among others, put up a project of the accession of the Crimea to Russia. Križanić considered that this would secure Russia's southern frontier; as for the Khanate's military potential, the writer considered it not very significant. Listing the benefits granted by the control of the Crimea, the Croatian mentioned commercial ports, the possibility of getting to the Black Sea via navigable rivers and, then, of using the Crimea as a base to establish trade with West Europe. Moreover, "the Crimean state is adorned and rich in many God's gifts": among these riches, there were products of farming, honey, horses, stone and ore mines, and woods [59, p. 117-119, 127]. The latter is nothing but idealization: the Crimea never possessed copper or silver, and the quality of local wood is doubtful. Križanić pointed out Crimean Tatars' military impotence and "discovered" potential allies of Russia among the Balkan and East European peoples oppressed by Muslims. Taking extraordinary natural and strategic advantages of the Crimea into account, the Croatian suggested to move Russian capital there, or to pass the Crimean government to Czar's brother. The conquered Tatars should be expelled from the country and replaced with "Russians, Poles, and Slovenians" [59, p. 120, 130-131]. However, it is still not clear if the message reached its addressee.

Several interesting points among Križanić's arguments deserve attention since they anticipated the ideas brought up in the late eighteenth and early nineteenth century. References to classical and mediaeval history of the Crimea, the flourishment of international trade in that period in particular [59, p. 119-120, 127], would become a popular argument in various "Crimean projects" after 1783 substantiating the plans for the economic development of the country [29]. However, it was an overestimation, and many landowners, merchants, and farmers who came to the peninsula were finally disappointed, and many businesses failed [55, p. 37-52, 81-86, 236-241, 292-296]. Križanić's point that the Crimea initially was not Muslim but belonged to Christians, justifying its future "return" to Christianity [59, p. 130], antedated the rhetoric of Catherine II [see about the latter: 80, p. 95-102]. Important are the Croatian's words that Russia could find allies for 
the conquest of the Crimea among the residents of the Don and Dnieper areas (Cossacks?) and also Poles [59, p. 118, 129]. Križanić might heard something on Koniecpolski's "Crimean project": in 1659, he visited Ukraine and collected various data concerning the Cossacks and Polish-Cossack-Tatar relations [31]. However, there is no doubt that the learned Croatian was able to develop the said ideas independently. Finally, it is worth mentioning the similarity of his interpretation of Russia as a patroness of oppressed Slavs on the Balkans and that of Patriarch Paisios I of Jerusalem (?-1660), who, being in Moscow in 1649, urged Alexis I to make a campaign against Constantinople to "liberate" Orthodox Ottoman subjects [65, p. 71-72, 173]. This is the origin of the ideas existing in the discourse to these days.

There is a hypothesis that among the readers of Križanićs treatise were Czar Alexis, his son Fyodor III (1661-1682, reigned from 1676), Vasiliy Golitsyn (16431714), a favourite of Princess Sophia (1657-1704, regent in 1682-1689), and the Scottish general in Russian service Patrick Gordon (1635-1699), and therefore it influenced Russian foreign policy in the second half of the seventeenth century [13, p. 14, 21, 24 25]. However, no direct arguments have been presented, except for, allegedly, Križanić's manuscript resided in Golitsyn's library. Among the indirect arguments probably was Russia's active policies on the south. It was January 1684 when Gordon presented Golitsyn his own ideas concerning the counter-Ottoman alliance with the Holy Roman Empire and Rzeczpospolita, and also a campaign against the Crimea.

Possibly trying to guess the favourite's own desires, the Scot stated that he would prefer peace to war, but later supplied a list of arguments in favour of the latter. Gordon was confident that the triumph over the Tatars was an easy matter; and this "pleasing to God" action would destroy the state menacing the Christian world for centuries. Christian slaves would be liberated. Golitsyn would win laurels, and Russia would enrich herself with countless treasures of the Crimean Tatars [23, p. 7-11]. It would be not difficult to see the difference between this rhetoric and Križanić's. What is most important, Gordon said nothing about the future status of the Crimea after the Russian victory. When a few years after, Golitsyn organized and led Crimean campaigns of 1687 and 1689 , these raids appeared not so easy a task as Gordon thought [63, book 7, p. 391-393, 405-410]. In that time, among the goals of the Russian government was to make the Crimean khanate a subject of Moscow [30, p. 397; 9, p. 318, n. 2]. Particularly, propaganda materials intended for the readers in the West stated the plans "to devastate all the Crimea, and to populate the Crimean land with Russian Cossacks and loyal Tatars (...) And we hope, with Lord's help, that soon the Crimean khan will write himself as Czar's subject" [11, p. 39]. This is not at all what Križanić wrote about. The learned Croatian proposed to eliminate the Muslim polity and to baptise or expel its inhabitants, but Golitsyn wished simply to change the khan's subjection, quite in the tradition of the passing-away feudal era.

In the early eighteenth century, the initiative to accept Russian subjection came from Crimean Khan Devlet Girey II (1648-1718, reigned in 1699-1703, 1708-1713, and 1716). This was facilitated by Russia's strengthening in the south after Peter I (1672-1725) ascended to power in 1689 and conquered Azov in 1696. In this period, the Khanate was involved in internal struggle, aggravated by the intervention of Constantinople and rebellions of some Nogay hordes, which lived outside the Crimea and expressed their desire to accept Russian subjection. The negotiations with the Khan were secret, conducted through intermediaries, and resumed several times; initially, Russia was not ready for such a radical measure. However, the Russo-Ottoman war of 1710-1713 made the Czar to change his mind, and he expressed his readiness to make a treaty with the khan and to accept him as subject. However, by that moment Devlet 
Girey II dropped off the idea of Russian alliance. Moreover, it is not quite clear if he sincerely planned to change his subjection, or used the negotiations to probe into Russia's plans [8].

Simultaneously, Peter I thought over the conquest of a fort in the Crimea. As early as 1698 and 1699, during the negotiations with Austria about the counter-Ottoman alliance, where the Czar participated in person, Russian representatives expressed their desire to have a stronghold (the name of this fort was not mentioned) in the Crimea [53, p. 259]. Tradition relates this episode is related to the town and fortress of Kerch, on the easternmost tip of the Crimean Peninsula, which controlled the passage from the Azov to Black Sea. Russians made the demand to the Ottomans concerning the transfer of Kerch also during the peace negotiations in 1698-1699 [51, vol. 9, col. 205; 61, p. 64, 66]. However, both the Austrians and Ottomans considered it too much. Later on, piece was concluded with the Ottoman Empire, and Peter I's attention shifted to the north, so the "Kerch Project" was set aside with ease [49, p. 512-513, 521-523]. Anyway, the Western mind kept memories of the Russian Czar's aggressive plans.

Perhaps these events were reflected by Jonathan Swift (1667-1745), who, among other things, was a political pamphleteer of importance and was afraid of Russia's successes [3, p. 81-82]. In his Country Life, the poet was afraid of the approaching Russia: "Why, Muscovy is not so far: / Down the Black Sea, and up the Straits, / And in a month he's at your gates..." [66, p. 204]. Swift definitely felt some "Russian threat".

British engineer John Perry (1670-1732) spent more than 10 years in Russia serving to Peter I. After returning home, he published a book on Russia where stated that the Czar could conquer the Crimea in the future "if the Princes of Christendom should again be jointly engaged in a War with the Turks..." It will be a revenge for the many years when the Tatars invaded Russia, made the czars their tributaries, and submitted them to humiliating rituals. Perry contended that he "often heard" that Peter I stated his plans to "make himself Master of Kertzi [Kerch], and have that the Place of laying up, and Rendezvous for his Navy..." [52, p. 139-140]. Perry's book became popular and appeared among the sources whence Western Europeans took information of Russia.

This book appeared when the memories of the Russo-Ottoman war of 1710-1713 were still fresh. It is interesting that initial plan of the Russian campaign in this war (1711) did not include an invasion into the Crimea. Later on, it was corrected to include a Cossacks' raid on the peninsula, which nevertheless was never realized [9, p. 51, 87]. Russia's "Crimean plans", imagined or real, became a propaganda tool of her enemies. The Swedes, Frenchmen, Poles, and Crimeans scared the Ottoman government informing it that Peter I was preparing an invasion to the Black Sea area and the Balkans, with the final goal to separate European provinces off the Porte [9, p. 34]. By all appearance, it corresponds to the Czar's epistles calling up the Slavic peoples to uprising [see 61, p. 7273], but it still remains not clear if he really wanted to "liberate" Balkan Christians or simply provoked an uprising in the Ottomans' rare to draw some of their troops away from the northern Black Sea area. On March 9, 1711, the Zaporozhian Cossack Hetman Pylyp Orlyk (Filip Orlik, 1672-1742), who signed a treaty of alliance with the Crimean Khanate, called upon the residents of Little Russia (Ukrainian Dnieper area) to struggle against Moscow, accusing Peter I in having intention to "enslave the Tatars" and "to attack the Crimea by military action and to take it as a region" [44, p. 227]. More than 50 years after, in the correspondence to Empress Catherine II during the Russo-Ottoman war of 1768-1774, Voltaire referred to the intention of Peter I to move the Russian capital to Constantinople like it was a well-known fact [72, p. 25, 233]. 
A new interest to the Crimea appeared in result of the Russo-Ottoman war of 17351739. The Russian commander-in-chief on the south was Field Marshal Burkhard Christoph von Münnich (1683-1767). In a letter of April 14, 1736, to the favourite of Empress Anna I (1693-1740, reigned from 1730), Ernst Johann von Biron (1690-1772), von Münnich stated his ambitious plan of seizing Constantinople and proclaiming Anna the Greek Empress. A stage in this grandiose project was the conquest of the Crimea [7, vol. 2, p. 509-510]. On August 11 von Münnich reported to the Empress of his plan to force the Tatars "to bring their obedience to Your Majesty" [74, p. 128; 79, p. 15]. This document is related to the famous campaign undertaken by von Münnich, when the Russian army, first time in history, entered the Crimea and devastated a great part of it, but had to retreat and suffered big losses due to the logistic reasons, the lack of water, food, and forage. There are demonstrative memoires of Christoph Hermann von Manstein (1711-1757), von Münnich's aide-de-camp and a participant of 1736 campaign, published when he left Russian service a couple of years after. According to him, the pretext for the war was "the desire of Russia to obtain satisfaction for the invasions of the Tartars" [40, p. 91, cf. p. 89-90]. As for von Münnich's scheme of action, "The plan which he had laid down for the campaign was, to begin with the siege of Azoph [Azov], and at the same time to make the greatest efforts against the Tartars of the Crimea, so as to conquer all their country if possible, and form a settlement on the Black Sea" [40, p. 95, cf. p. 111]. When the army reached Perekop, the fortification closing the isthmus connecting the Crimean Peninsula with the mainland, von Münnich sent a message to the Khan demanding him to "put himself under the protection of Her Imperial Majesty, receive a Russian garrison in Perekop, and bind himself to acknowledge the sovereignty of Russia..." [40, p. 105; cf.: 79, p. 61]. Demonstratively, later on, in 1739, being the commander of the Russian troop on the Danube, von Münnich planned the accession of Moldavia to Russia [34, p. 51]. It reveals that the Field Marshal consistently followed his counter-Ottoman grand projet.

During this war, Russian troops invaded the Crimea for three times $(1736,1737$, and 1738), but every time had to leave it. Whether due to Russian military successes or for other reasons, a split arose among both Ottoman and Tatar elites: some dignitaries were ready to agree to the Russian protectorate of the Crimea [17, p. 492-493, 498]. However, according to von Manstein there was no single opinion of the aim of the war among Russian leaders. In his words, some of the establishment, particularly the actual head of the foreign policy, Vice-Chancellor Count Heinrich Johann Ostermann (1686-1747), planned to wage war with the Crimea and not with the Ottomans, as a punitive action and not the conquest of territories [40, p. 96-97]. Anna I's manifesto of April 12, 1736 declaring the war to the Ottoman Empire also states simply the defence of Russia's southern provinces from the Turkish and Tatar raids [79, p. 16 and n. 2]. Later on, during the negotiations with allied state, Austria and hostile state, Turkey, Russian representatives claimed the Crimea many times. However, the Peace of Belgrade that finished the war did not mention the Crimea. Russia's modest acquisitions in this war, despite of her undisputed military successes, are explainable by the fear of having ally no more after Austria left the conflict, the danger of a possible conflict with Sweden, and economic problems caused by the strife [45, p. 188, 198-199, 201, 207, 210, 212, 216, 219-220, 235, 238, 267-268]. The Crimea was not so important to be struggled for.

In 1739, Italian adventurer Francesco Algarotti (1712-1764) visited St. Petersburg. In his travel journal he stated his considerations concerning the current RussoTurkish war. Importantly, Algarotti never was to the Black Sea area, so he could only rely on the information received from his acquaintances in the Russian capital. Thinking of Russia's foreign political interests, the Italian supposed that a stronghold in the 
Crimea was important for the Russians to ensure security against the Ottomans and Tatars. The town of Kerch with its strategic position and excellent harbour would be of great use for Russia's establishment herself on the two seas. In Algarotti's words, it was the plan of Peter I [5, p. 89]. More than 20 years after, the Italian published a book on Russia based on his journal (1760). This extraordinary popular book was re-issued many times and in different languages: particularly, it donated the image of St. Petersburg as the "window to Europe" to Russian culture. Among other issues, Algarotti wrote down his understanding of Russia's aims in the war of 1735-1739. In his opinion, Czarina Anna tried to realize the plans once developed by Peter I: to take possession of the Crimea, this "granary of Constantinople", and to establish a fleet on the Black Sea. Finally, "if fortune continued to be favourable, much more might be expected": the Czarina would be able to expel the Ottomans from Europe [4, p. 173-174]. Therefore, the conquest of the Crimea was only a stage in the struggle against the Ottoman Empire. The Italian underlined that the raids of the Tatars were a permanent menace to Russia's southern provinces, and repeated the idea of Kerch as the ideal stronghold in the Crimea that should be taken by Russia [4, p. 127-128, 150-155]. Algarotti's description of the Russo-Turkish war and Russian invasions follows epic style, with references to the episodes of ancient Roman history and underlining that the victories were gained due to progressive western warfare. However, the author was disappointed with the Russian army's decision to leave the Crimea after devastating it: perhaps he considered that the war is not successful without annexation [4, p. 155205]. Although it is not quite clear if Algarotti's thoughts were original or simply reflected his talks with some persons in St. Peterburg or Perry's book, they, nevertheless, possibly influenced Western public mind simply because of the popularity of this book.

A year before that (1759), there appeared another famous book, Voltaire's (16941778) History of Peter the Great, Emperor of Russia. The French philosopher drew the principal differences between the policies of his hero and Golitsyn's Crimean Campaigns. The Czarina Sophia's favourite started the war in order to take revenge of the "most intolerable circumstance for their empire" - an annual tribute to the Crimean khan [73, p. 68]. In contrast, Peter I acted as an "enlightened monarch", with the aim of getting "progress" and "civilization" to his country and new lands. According to Voltaire, after taking possession of the castle of Azov, the Czar improved its harbour for holding large vessels "with a design to make himself master of the Straits of $\mathrm{Caffa}^{1}$, or the Cimmerian Bosphorus, which commands the entrance into the Pontus Euxinus, or Black Sea..." [73, p. 88]. The aim was to "restore" international trade which was considered, in the Enlightenment, a symbol of progress; moreover, he followed the example of ancient Greeks understood as a sample and model. "The czar's scheme was to drive the Turks and the Tartars for ever out of the Taurica Chersonesus [Crimea], and afterwards to establish a free and easy commerce with Persia through Georgia" [73, p. 88]. Both the reflection on perspectives of trade and reference to classical history resembles Križanić's. Voltaire certainly had no idea of the learned Croatian's book, but the similarity of thinking was remarkable. Voltaire's history of Peter I was ordered by the Russian government, which supplied the historian with abundant materials. The book of Perry was among Voltaire's sources [1, p. 159-160], whence the philosopher could borrow the account of the Czar's hypothetical plans on the Crimea. Another possible source is conversation with von Manstein. In 1752, Voltaire assisted the German in his work on the Russian memoires [36, p. 83] and, therefore, could get from him information on von Münnich's views of the "Crimean" and "Ottoman" questions.

${ }^{1}$ The writer confused Caffa (present-day Feodosiya) with Kerch, which laid on the side of the straits connecting the Azov Sea and the Black Sea. 
Von Manstein's memoires inform that Peter I prepared war with the Ottomans: "in short, everything was ready for taking the field, when death prevented the execution of his designs" [40, p. 90]. The Crimea was not mentioned in this context: however, as we can see later on, von Münnich would refer to Peter I when substantiating his "Crimean project".

It was the time when famous modern Greek writer and poet Constantine Dapontes (1713/14-1784), who visited the Crimea in 1746-1747, described his travel in a poem entitled Women's Mirror (1766). In fact, he was the first who acquainted the people of modern Greek language and culture with the present and not the past of the Crimea. Particularly, Dapontes hoped that once Russia would "draw Muhammad out" of the Crimea. In his view, it will make the first step towards the liberation of all oriental Christians from the Ottomans. So, the poet dreamt of the freedom for Greece, and the joining of Crimea to Russia would be the first stage of this "Orthodox Reconquista" [2, p. 615-616]. By that moment, the idea of Russia as a patroness of all Orthodox people became a common place; as an example, the leader of Montenegro Vasilije PetrovićNjegoš (1709-1766) presented Empress Elizabeth I (1709-1761, reigned from 1741) a project of unification of the Balkan Slavs under his leadership and Russian protectorate $[65$, p. 233].

In 1762, just after Catherine II's (1729-1796, reigned from 1762) ascension to the throne, she received several projects of the accession of the Crimea. Chancellor Mikhail Vorontsov (1714-1767) in his report On the Tataria Minor suggested the conquest of the Crimea due to military-strategic reasons: to eliminate the possibility of raids of the Tatars, their permanent conflicts with the Cossacks, and "troubles with the Porte" caused by the Khanate. A special point stated that the establishment of control over the Crimea would allow Russia "to attract all the commerce" with "nearby eastern and southern countries" [7, vol. 25, p. 308-312].

In the same year, von Münnich sent a letter to the Empress assuring that he had "well-founded arguments": for 30 years Peter I was cherishing a hope "to make the Conquest of Constantinople, to expel infidel Turks and Tatars from Europe and thus to restore the Greek monarchy" [68, p. 467]. Although the nature of these "well-founded arguments" remains unclear, von Münnich entered the Russian service in 1721 and many times conversed to the Emperor [78, p. 82-83, 207-209]. Von Münnich wrote to Catherine II that, during his exile in Siberia (1742-1762), he developed a general plan of this "great and important enterprise". A part of it should be the conquest of the Crimea. The Field Marshal assured that, due to his experience obtained in the campaign of 1736, he was well acquainted with the difficulties of expedition to the peninsula and the ways of overcoming them. However, he did not go into details [68, p. 467]. Noteworthy, von Manstein, who kept warm relations to his chief, nevertheless considered it necessary to mention in his memoires that the latter "knew nothing of the Crimea but what he had learnt from the Cossacks, who had been there in the course of their trade, and he believed that as it was an extremely fertile country, the army would, as soon as it arrived there, find subsistence enough in the enemy's territories, without needing adventitious supplies" [40, p. 101-102]. In the upshot, no "subsistence" was found, and the army appeared in a trap. Did von Münnich learn his lesson of this campaign? Be that as it may, he never abandoned his plans concerning the Crimea and Constantinople, and, the more so, skilfully used the name of Peter I to add more value to his arguments. It is interesting that his correspondence to Catherine II was published in Germany 20 years after, on the eve of the accession of the Crimea to Russia.

Demonstrative is that, later on, some of the foreigners related the project of expelling the Ottomans from Europe and "restoration" of Byzantium with Münnich and not 
with Voltaire, Algarotti, or some other person. This way, French Baron Charles de Baert (1750/51-1825), who visited the Crimea in 1784, in his travel journal attributed this project to Peter I referring to Münnich's letter to Catherine II. According to de Baert, the Empress approved the project and worked on it in a consistent manner [42, p. 27].

In 1769, German-by-origin adventurer and French subject Count Sigismund von Redern (1719-1789) presented to Catherine II his project of the annexation of the Crimea and then Constantinople, with the aim of establishment of a company to trade with the East. The example was the British East India Company. The structure imagined by von Redern should have a series of state functions, such as judicial immunity, the right of waging war, its own army, navy, etc. However, the Empress rejected this project, probably because she understood its fantastic nature [64, p. 222-224].

It is well known that Voltaire (1694-1778), in his correspondence to Catherine II, inclined the Empress to wage war against the Ottomans in order to expel them from Europe and to "restore Greece" [80, p. 30-36]. He remembered the Crimea much rarely than Athens or Constantinople. Thus, in a letter of July 30, 1771, the philosopher asked the Empress "if it is true that you took possession of entire Crimea?" [72, p. 148]. Voltaire admired that now Russia seized the country which once had been a scene of ancient Greek myths and called upon to go the extra mile: "But if, after the conquest of this Tauric Chersonese [Crimea], you donate peace to Mustapha [Ottoman sultan], what will happen to the good land of Demosthenes and Sophocles? (...) should I reject all my beautiful illusions?" [72, p. 149]. Obviously, the French supplied the Crimea with no independent significance, considering the peninsula only the first stage in the grandiose counter-Ottoman design.

In the same letter, Voltaire proposed Catherine II to show tolerance to the Crimean Tatars, an idea not very typical to his time: "If Your Imperial Majesty keeps Chersonese, which I believe, you will add a new chapter to your code [of law] in favour of the Muslims who live in that region. Your Greek church (...), no doubt, will not make many conversions; but it will be able to establish grand commerce. There was [trading] in the past between this Scythia and Greece" [72, p. 149-150]. As it has already been mentioned, references to the Greco-Roman past as the background for modern commercial projects was typical of some intellectuals in the Modern Period. It is demonstrative that Catherine II assessed perspectives of the current war in much more realistic way: "If we take one or two Caffas more, the war will be repaid" [72, p. 152]. The empress instructed her representatives in the Crimea to demand even three ports from the khan [28, p. 16-17].

On March 15, 1770, the Council of State of the Russian Empire decided to continue the war until the Port would recognize the independence of the Crimea [17, p. 510; 48 , p. $121 ; 71$, no. 4 , p. 124]. Among the considerations remarkable is the following: "Crimean and other Tatars under their khan, due to their quality and location, will never become useful subjects of Her Imperial Majesty, and, first, no fair taxes can be collected from them, and, second, [they] will not serve to protect Her borders...". Therefore, "as little use would Russia have from the subjection of this peninsula with other Tatar hordes belonging to it, as much and noble, on the contrary, could be the increase of the Russian forces and might if they are taken away from the Turkish power and left independent forever..." [6, col. 43-44]. This decision was certainly inspired by Catherine II, who planned to separate the Crimea from the Ottoman Empire by making it an independent polity. Her rescript of April 15, 1770 given to General Petr Panin (1721-1789) who was fighting with the Turks and Tatars in the northern Black Sea area stated: "It is not Our intent at all to have this peninsula and the Tatar hordes that 
belong to it under our jurisdiction, but it would be desirable if they were removed from Turkish dominion and remained forever independent. Due to the Crimea's position and that of those places where Tatars live outside of it, and no less due to their character, they will never be the subjects of use to Our empire, [because] no significant taxes can be collected from them, and they will not serve to defend its borders (...) However little benefit may be to Russia from the subjection of the Crimea and the Tatar hordes, but on the contrary, great and noble may be the gain of Russian strength and power from their separation from Turkish power and establishment of their independence and their own freedom...". Catherine II was quite happy with the establishment of control over the forts of Enikale and Taman which sat on the opposite sides of the Kerch Straits and controlled the passage from the Azov to Black Sea, thus allowing the Empress to command the military-political situation in the region and to secure the freedom of navigation [75, p. 1-3]. The same point occurred in the Empress' rescript of May 20, 1771 to General Evdokim Shcherbinin (1728-1783), who was then in the Crimea, allowing to support the election of Shahin Girey (1745-1787, reigned in 1777-1783) as the new khan, with the condition that the latter "give a pledge from himself to be the Khan of all the Tatar hordes which separated from the Ottoman Porte, binding himself in addition to remain forever independent and in alliance with Our Empire" [67, p. 48].

Consequently, Catherine II's plan foresaw not the widening her empire, but rather securing its southern and western borders with creating there several buffer states, independent de jure and controlled by Russian de facto, such as the Crimea, Danubian principalities, and Poland [71, no. 3, p. 136, 138-139, 148, no. 4, p. 124-127, 131-132, no. 6, p. 120, 135]. It was quite another matter that the development of dynamic international situation made the Empress to change her plans. It has been rightly observed that this political scheme corresponded to the political ideas of Charles de Montesquieu (16891755), the "virtual mentor" of Russian Empress [47, p. 116; cf. 43, p. 132]. These plans were perfectly understood by British diplomats. The Ambassador to Russia Lord Charles Cathcart's (1721-1776) report to London on June 30, 1769 mentioned the Russian "project of erecting Tartary, Moldavia and Wallachia into independent States as a defence against Turkey, and the idea (...) of forming a barrier against Sweden, by erecting all Finland into an independent Great Duchy..." [18, vol. 12, p. 460-461].

The Empress" "Crimean plans" were realised in result of the Russo-Ottoman war of 1768-1774 and secured in the Treaty of Karasu Bazaar with the Crimean Khanate (1772) and the Treaty of Küçük Kainarca with the Ottomans (1774). Russian bases appeared in the fortresses of Kerch and Enikale in the eastern Crimea to control the passage from the Azov to Black Sea $[19 ; 28]$. Russian troops were almost permanently stationed in the peninsula. It is worth mentioning another Lord Cathcart's dispatch informing London that, on the eve of (unsuccessful) negotiations of Russia and Turkey about peace in 1771, he got information about the Empress' secret plan, according to which Russia should declare her pretension to the Crimea, in order to reject it later and agree with the independence of the Khanate: "She [Catherine II] lays an ancient claim to the sovereignty of the Tartars already free, and that of those of the Crimea; but, relinquishing that right, insists upon their independency under their own khan..." [18, vol. 19, p. 190-191]. It resembles the ways of negotiating under Peter I and Anna I, as stated above.

In 1775, the head of the British foreign office Earl Henry Suffolk (1739-1779) instructed the Cathcart's successor as the British ambassador to Russia Robert Gunning (1731-1816) that, in his view, now the Crimea "though nominally independent, may be considered as an effectual appendage of Russia" - in result of the Treaty of Küçük 
Kainarca [18, vol. 19, p. 443]. It means that the British understanding of the new state of the Crimea differed from Catherine II's, but still it was more realistic from the point of view of future developments. It is interesting that modern scholarship often had the same view as Earl Suffolk, interpreting the new status of the Khanate as the "so-called independency", which in fact was Russian protectorate and the first stage on the way to the accession to the Czarina's empire. However, the analysis of the documents in possession shows that such an interpretation arises from hindsight bias or confirmation bias: in fact, there was an alternative way of the Crimean history [48; 76, p. 76-80]. The Khanate might keep its (semi-)independency as a Russian protectorate. The thing is that, even with all Russia's desire to retain the new status of the Crimea, the local state and society would have to change in order to adapt to the new reality. This status was an opportunity and not something "established forever". The histories of buffer states on Russian borders followed various paths. The hordes of the Kazakh steppe were gradually absorbed and integrated by Russia [69]. Poland was partitioned and, by parts, integrated into three European empires [77]. The Danubian principalities lost some of their lands (Russia annexed Bessarabia and Austria appropriated Bukovina) and kept their buffer status in the nineteenth century and finally evolutioned into the Kingdom of Romania [34, p. 42-60].

Be that as it may, the post-1774 situation activated reflections on the future of the Crimea. It was 1774 when Pavel Levashov (1719?-1820), a Russian diplomatist who just returned from Constantinople, wrote a treatise entitled The Picture, or Description of All the Invasions of the Tatars and Turks of Russia. In his own words, he tried to stimulate the "descendants" to "conquer the Crimea and other regions lying near it" [35, p. i-ii]. In other words, the author viewed this goal as a remote perspective. Levashov suggested a few arguments supporting Russia's rights for the Crimea. Firstly, by the "right of ownership", since the peninsula once belonged to the Scythians, whom the author considered the forefathers of the Russians. Secondly, by the "right of conquest", since Rus'ian princes Vladimir the Saint (ca 955-1015) and Vladimir Monomach (1053-1125) conducted successful raids on the Crimea. Thirdly, by the "right of inheritance", resulting from marriage connections between the Russian rulers and the Chinggisids. Fourthly, by the "right of might", i. e. military superiority, which previously belonged to the Tatars, who established their control over a greater part of modern Russia [35, p. 150-163]. The first and second arguments anticipated the rhetoric of Russian ideologists after 1783 [80, p. 95-97]. Also interesting are Levashov's considerations that the Crimea should become a foothold to develop international commerce "especially if at least some part of Indian trade would be turned there via the Caspian, Azov, and Black Sea". The author supported this idea with references to the cases of bygone days: commercial enterprises of Hellenes and mediaeval Genoese and Venetians who did successful trading in and via the Black Sea [35, p. 164-167]. This logic is noteworthy similar to the reflections of his contemporaries on the European West and the old ideas of Križanić. Levashov's book was published only 18 years after, when the "Crimea problem" was already solved. However, his ideas influenced some of the members of Russian elite.

In 1776, Catherine II's Secretary of State, Aleksandr Bezborodko (1747-1799), presented the Empress a memoir of the Crimean Tatars [25, p. 339-370]. It actually was nothing but inconsiderably revised Levashov's document, with an original conclusion stating that, under present circumstances, the conquest of the Crimea would not be hard, but it would save Little Russia of devastating Tatar raids [25, p. 369-370]. Later on, in an autobiographical memoir, Bezborodko assured that in the next year of 1777 he informed the Russian government that "their [Crimean Tatars] independence is 
insecure for us, and there is need to consider the appropriation of this peninsula" [25, p. 93, 444]. Among the documents from the office of Prince Grigoriy Potemkin (17391791), the almighty governor of southern provinces of Russia, there was an anonymous paper "on the former affairs with the Tatars", probably compiled in several steps in the 1770s [70]. It started with a historical note concerning the long confrontation between Russia and the Tatars, which was copied from the document of Levashov (or Bezborodko). The second part suggested a plan for the conquest and accession of the Crimea and its colonization with Orthodox population from Russia and Europe. Another document from the same archive was written by Potemkin to offer arguments for the annexation of the Crimea: perhaps these draft notes were used in 1782 when he was convincing Catherine II to make such a decision [70, p. 125-126; cf. 20, p. 154-155]. Be that as it may, these documents reflect a part of the Russian elite's aspirations towards the Crimea. They might well be connected to the discussion on the future of the peninsula among the Russian establishment in 1777-1778, when internal struggle in the Crimea aggravated [17, p. 528-529]. It is interesting that there were foreigners getting similar ideas. British Reginald Pole Carew (1753-1835), who visited the Crimea in 1781 as a part of his Grand Tour, later wrote to Prince Potemkin that Russian "protection" would be a benefit for the Crimea [14, p. 353, 355].

Catherine II refrained from taking radical steps towards the Crimea, probably trying to keep status quo as long as possible [15; 16; 38; 48; 71, no. 4, p. 125-127]. However, as it turned out soon, the Crimean Khanate proved incapable of independence. The internal instability of the Tatar polity was impeded by tense international situation with the Ottoman and Russian Empires struggling for the influence on the Crimea and supporting alternative pretenders to the khan's throne [see details at 17, p. 515-538]. When the Russian leaders finally understood that their policy of "stability enforcement" did not work, a radical solution was adopted. The decision to liquidate the Khanate and annex its lands to Russia was made only in late 1782 under the influence of Potemkin, who was in the south and had full knowledge of the crisis [38]. On December 14, 1782, the Empress signed the "most secret" rescript to Potemkin ordering to annex the Crimea "at the convenient time" [12, p. 221-225].

The accession of the Crimea manifesto was signed on April 8 but published on July 21,1783 in order to gain time to arrange the affairs in the Peninsula peacefully and to fix everything with foreign powers [see: 39, p. 284-294]. This manifesto quite frankly explains the former political scheme of keeping the Khanate independent: "In the past war with the Ottoman Porte, when the forces and victories of our weapons gave us the full right to keep in our own advantage the Crimea, which was in our hands, then we sacrificed this and other vast conquests to the renewal of good accord and friendship with the Ottoman Porte, having transformed at that time the Tatar peoples into a free and independent region, so as to remove forever incidents and ways of quarrels and disagreement, which had frequently occurred between Russia and the Porte under the former state of the Tatars (...) But now, when, on the one hand, we are taking into account considerable costs incurred so far on the Tatars and for the Tatars, which according to correct calculation exceed twelve million roubles, not including here the loss of people, which is higher than any monetary value; and on the other hand, when it became known to Us that the Ottoman Porte starts exercising the supreme power over the Tatar lands (...); and for that, according to Our duty of care for the wealth and greatness of the homeland, trying to establish its benefit and security, (...) and no less in replacement and satisfaction of our losses, We decided to take the Crimean Peninsula under our power..." [54, p. 897-898, no. 15708]. In the same day, April 8, the Empress repeated these theses in a shortened form in the rescript given to 
the ambassador in Constantinople, Yakov Bulgakov (1743-1809), adding that: "little time passed when we started understanding from experience that the Tatars, from their ignorance and savageness, are not able to exist in the form of a free and independent region" [50, p. 121, 261]. Here Catherine II used counter-Tatar rhetoric ("ignorance and savageness") typical both for Russia and West Europe of her age. Russian eighteenth-century culture featured negative relations to Muslims as its contrariety and existential enemy [10, p. 51-59]. Many influential contemporaries of the Russian Empress, such as Johann Gottfried Herder (1744-1803) or Jean-Jacques Rousseau (1712-1778) actually feared the "Islamic threat" and understood the Turks and Tatars as enemies $[27$, p. $485-486 ; 58$, p. 53]. Finally, some of the points of Catherine II's accession manifesto repeated those of the above-mentioned rescript of December 14, 1782, where it stated the "Tatar peoples" inability to exist independently, permanent need to use Russian troops to keep stability in the Crimea, enormous expenses born by Russia for support of the Khanate's independence (however the amount in the manifesto almost doubled), and the loss of people "which exceed any cost" [12, p. 222].

To sum up, the discussion of the possible accession of the Crimea to Russia started possibly in the mid-sixteenth and certainly in the seventeenth century. It was debated for long both in Russia and in the countries located to the west of it, with participation of politicians and writers, historians and travellers. Sometimes it was even more acute in Western Europe than in Moscow or Petersburg. Therefore, the accession of the Crimea was not only a product of the "Russian imperialism": West and Central European public thought considered it a fully allowable measure directed on the "historical progress", as they understood it. Certainly, some of the authors of the "accession projects" were engaged in the Russian service (like Gordon or von Münnich); others petitioned to Russian rulers with their plans (like Križanić or von Redern); the third established close relations to Russia (like Voltaire). However, there still were independent thinkers (like Koniecpolski, Algarotti, or Dapontes). Therefore, it is likely that, at least in some cases, they were influenced by general counter-Islamic (counter-Turk, counter-Tatar) attitudes of the Western culture [on that aspect see: 46, p. 39-55] rather than Russian political ideas. Be that as it may, this discussion attracted various arguments: initially there was primarily counter-Muslim rhetoric, underlining the existential opposition of Christianity and Islam and the need of "returning" the lands which formerly belonged to Europe. The age of Enlightenment gave birth to the ideas of Europe's civilizing mission and trade as the core of the progress impeded by "inactive" Muslim society. Sometimes the discussion participants put up original arguments, and sometimes their dependency from the predecessors is traceable. The sources in possession have shown that Russia never had a purposeful and long-time strategy on the "Crimea question": particular Czars evaluated particular situation of their own time and acted according to their own understanding of what was happening. Sometimes, there was no agreement among the imperial elite concerning the Crimea, and sometimes the country was used to raise the stakes in international negotiations and to be "exchanged" for something during a haggle. In Russia, the discussion of the future of the Crimea became especially acute in the second and third quarter of the eighteenth century, probably when the elite understood that the development of the Empire made the conquest of the peninsula real. It is not quite clear if the reflections of popular western authors like Voltaire or Algarotti influenced the Russian government. However, it seems that their contribution made the western powers' reaction on the 1783 events rather reserved: the mind of the Europeans was already prepared to this kind of development. But later on, the foreigners produced different evaluations of the Crimea's accession to Russia. Some of them viewed it as a progressive phenomenon opening perspectives for various commercial, economic, and cultural developments, though the 
others created the discourse of the "Golden Age" of the Crimean Khanate which was cruelly destroyed by the conquerors and even advocated for the "return" of the peninsula to the Ottomans $[55$, p. $75-88 ; 29$, p. 59-70].

\section{REFERENCES}

1. Al'bina L.L. Istochniki “Istorii Rossiyskoy imperii pri Petre Velikom" Vol'tera v ego biblioteke [The sources of Voltaire's "History of the Russian Empire under Peter the Great" in his library]. Problemy istochnikovedcheskogo izucheniya rukopisnykh $i$ staropechatnykh fondov [Aspects of Source Studying Research of Manuscript and Old Style Collections]. Leningrad: State Public Library, 1980, vol. 2, pp. 153-170. (In Russian)

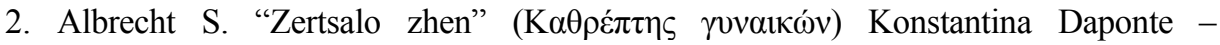

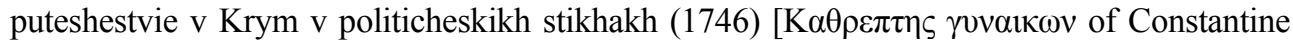
Dapontes - the trip to the Crimea in political verses (1746)]. Materialy po arkheologii $i$ istorii antichnogo i srednevekovogo Prichernomor'ya [Proceedings in Archaeology and History of Ancient and Medieval Black Sea Region]. 2019, no. 11, pp. 609-631. (In Russian)

3. Alekseev M. P. Russko-angliyskie literaturnye svyazi (XVIII vek-pervaya polovina $X I X$ veka) [The Russian-English Literature Connections (eighteenth - first half of nineteenth century)]. Moscow: Nauka, 1982. 863 p. (In Russian)

4. Algarotti F. Letters from Count Algarotti to Lord Hervey and The Marquis Scipio Maffei, Containing the State of the Trade, Marine, Revenues, and Forces of the Russian Empire: With the History of the Late War between the Russians and the Turks, and Observations on the Baltic and Caspian Seas. London: Johnson and Payne, 1796, vol. 1. 205 p.

5. Algarotti F. "Okno v Evropu": dnevnik puteshestviya iz Londona v Peterburg v 1739 godu ["A Window to Europe": Travel Journal from London to Petersburg in the Year 1739]. Moscow: Staraya Basmannaya, 2016. 164 p. (In Russian)

6. Arkhiv Gosudarstvennogo Soveta [The Archive of the Council of State]. St. Petersburg: Printing House of the Second Section of His Imperial Majesty's Own Chancellery, 1869, vol. 1. 932 col. (In Russian)

7. Arkhiv knyazya Vorontsova [Prince Vorontsov's Archive]. Moscow: Publishing House of A.I. Mamontov and $C^{\circ}$, 1871, vol. 2. 642 p.; Moscow: University Typography, 1882, vol. 25. 514 p. (In Russian)

8. Artamonov V.A. Peregovory o perekhode Krymskogo khanstva v russkoe poddanstvo pri Petre Velikom [The negotiations on the transfer of the Crimean Khanate into Russian subjection under Peter the Great]. Slavyane $i$ ikh sosedi [The Slavs and Their Neighbors]. 2001, vol. 10, pp. 269-286. (In Russian)

9. Artamonov V.A. Turetsko-russkaya voyna, 1710-1713 [The Turko-Russian War, 1710-1713]. Moscow: Kuchkovo Field, 2019. 448 p. (In Russian)

10. Batunskiy M. Islam i russkaya kul'tura XVIII veka. Opyt istorikoepistemologicheskogo issledovaniya [Islam and the Russian culture in the eighteenth century: An essay of historical-epistemological research]. Cahiers du monde russe et soviétique. 1986, vol. 27, no. 1, pp. 45-69. (In Russian)

11. Bogdanov A.I. Vneshnyaya politika Rossii i evropeyskaya pechat' (1676-1689 gg.) [Russian foreign policy and European press (1676-1689)]. Voprosy istorii [Issues of History]. 2003, no. 4, pp. 26-46. (In Russian)

12. Bumagi imperatritsy Ekateriny II, khranyashchiesya v Gosudarstvennom arkhive Ministerstva inostrannykh del, tom 4 [The papers of Empress Catherine II residing in the State Archive at the Foreign Ministry, vol. 4]. Sbornik imperatorskogo russkogo istoricheskogo obshchestva [Proceedings of the Imperial Russian Historical Society]. 1880, vol. 27, pp. 1-600. (In Russian)

13. Chernikova T.V. Vliyanie idey Yuriya Krizhanicha na politicheskie nastroeniya moskovskoy elity [The influence of Juraj Križanić's ideas on the political aspirations of 
Moscow elite]. Slavyane i Rossiya: slavyane v Moskve [The Slavs and Russia: The Slavs in Moscow]. Moscow: Institute of Slavic Studies of the Russian Academy of Sciences, 2018, pp. 7-27. (In Russian)

14. Cross A.G. By the Banks of the Neva: Chapters from the Lives and Careers of the British in Eighteenth-century Russia. Cambridge: Cambridge University Press, 1997. 474 p.

15. Deynikov R.T. Ot vassal'nogo khanstva Osmanskoy imperii do Tavricheskoy gubernii v sostave Rossii [From the Khanate vassal to the Ottoman Empire to the Taurida Governorate as a part of Russia]. Otechestvennaya istoriya [Homeland History]. 1999, no. 2, pp. 80-88. (In Russian)

16. Deynikov R.T. Rossiyskie voennye i diplomaty o statuse Kryma v period pravleniya Shagin-Gireya [Russian military men and diplomatists on the Crimea's status in the Age of Shakhin Girey]. Moskva - Krym [Moscow - Crimea]. 2002, no. 4, pp. 50-59. (In Russian)

17. Deynikov R.T. Krymskoe khanstvo ot Konstantinopol'skogo mira do prisoedineniya k Rossii. 1700-1783 gg. [The Crimean Khanate from the Peace of Constantinople to the Accession to Russia, 1700-1783]. Istoriya Kryma [A History of the Crimea]. Moscow: Kuchkovo Field, 2018, vol. 1, pp. 485-538. (In Russian)

18. Diplomaticheskaya perepiska angliyskikh poslov i poslannikov pri russkom dvore [Diplomatic correspondence of English ambassadors and ministers at the Russian court]. Sbornik Imperatorskogo russkogo istoricheskogo obshchestva [Proceedings of the Imperial Russian Historical Society]. 1873, vol. 12, pp. 1-499; 1876, vol. 19, pp. 1-547. (In Russian)

19. Druzhinina E.I. Kyuchuk-Kaynardzhiyskiy mir 1774 goda (ego podgotovka $i$ zaklyuchenie) [The Peace of Küçük Kainarca of 1774 (Its Preparation and Conclusion)]. Moscow; Leningrad: Academy of Sciences of the USSR, 1955. 366 p. (In Russian)

20. Ekaterina II i G.A. Potemkin. Lichnaya perepiska, 1769-1791 [Catherine II and G.A. Potemkin. Their Private Correspondence, 1769-1791]. Moscow: Nauka, 1997. 989 p. (In Russian)

21. Filyushkin A.I. Izobretaya pervuyu voynu Rossii i Evropy: Baltiyskie voyny vtoroy poloviny XVI v. glazami sovremennikov i potomkov [Inventing the First War between Russia and Europe: The Baltic Wars in the second half of sixteenth century as Viewed by Contemporaries and Descendants]. St. Petersburg: Dmitriy Bulanin, 2013. 880 p. (In Russian)

22. Fisher A.W. The Russian Annexation of the Crimea, 1772-1783. Cambridge: Cambridge University Press, 1970. 180 p.

23. Gordon P. Dnevnik, 1684-1689 [Diary, 1684-1689]. Moscow: Nauka, 2009. 339 p. (In Russian)

24. Grigor'ev S.I. “...Kafir ves'ma krutogo nrava”: A.V. Suvorov i Krymskoe khanstvo (1771-1779) [“...A Kafir of Much Temper”: A.V. Suvorov and the Crimean Khanate (1771-1779)]. St. Petersburg: State Memorial Museum of Alexander Suvorov, 2015. 552 p. (In Russian)

25. Grigorovich N. Kantsler knyaz' Aleksandr Andreevich Bezborodko v svyazi s sobytiyami ego vremeni, ch. 1 [The Councilor Prince Aleksandr Andreevich Bezborodko in relation to the events of his age, pt. 1]. Sbornik Imperatorskogo russkogo istoricheskogo obshchestva [Proceedings of the Imperial Russian Historical Society]. 1879, vol. 26, pp. 1649. (In Russian)

26. Gurzhiy O.I. Problemy formuvannya pivdennykh gybernyi Rosyys'koï imperiï v politytsi Kateryny II [The Aspects of the Formation of the Southern Governorates of the Russian Empire in Catherine II's Policy]. Kyiv: Institute of History of Ukraine of the National Academy of Sciences of Ukraine, 2017. 76 p. (In Ukrainian)

27. Herder J.G. Outlines of a Philosophy of the History of Man. Churchill T. (tr.). New York: Bergman Publishers, 1800. 632 p.

28. Karasubazarskiy traktat 1772 goda: sbornik dokumentov [The Treaty of Karasu Bazaar in 1772: Collected Documents]. Simferopol: Antiqua, 2015. 120 p. (In Russian) 
29. Khrapunov N.I. "Aziatskiy mirazh" i budushchee Kryma: proekty zapadnykh intellektualov [The "Asian Mirage" and the future of the Crimea: Projects of Western intellectuals]. Rossiyskaya imperiya i Krym [The Russian Empire and the Crimea]. Simferopol: Publishing House of the Crimean Federal University, 2020, pp. 57-74. (In Russian)

30. Kochegarov K.A. Rech' Pospolitaya i Rossiya v 1680-1686 godakh. Zaklyuchenie dogovora o Vechnom mire [Rzeczpospolita and Russia in 1680-1686: The Conclusion of the Treaty of Eternal Peace]. Moscow: Indrik, 2008. 504 p. (In Russian)

31. Križanić J. Malorusskie kazaki mezhdu Rossiey i Pol'shey v 1659 godu [The Little Russian Cossacks between Russia and Poland in 1659]. Chteniya v Imperatorskom moskovskom obshchestve istorii $i$ drevnostey rossiyskikh pri Moskovskom universitete [Readings at the Imperial Moscow Society of Russian History and Antiquities at Moscow University]. 1876, vol. 3, sect. 5, pp. 109-124. (In Russian)

32. Kulish P.A. Otpadenie Malorossii ot Pol'shi (1340-1654) [The Separation of Little Russia from Poland (1340-1654)]. Moscow: University Typography, 1888, vol. 2. 399 p. (In Russian)

33. Kurbsky A. Istoriya o delakh velikogo knyazya moskovskogo [A History on the Affairs of the Grand Prince of Moscow]. Moscow: Nauka, 2015. 942 p. (In Russian)

34. Kushko A., Taki V., Grom O. Bessarabiya v sostave Rossiyskoy imperii (18121917) [Bessarabia as a Part of the Russian Empire, 1821-1917]. Moscow: New Literary Review, 2012. 400 p. (In Russian)

35. Levashov P. Kartina, ili opisanie vsekh nashestviy na Rossiyu tatar $i$ turkov [A Picture, or Description of All Invasions of the Turks and Tatars of Russia]. St. Petersburg: In the house of G. Zubov, 1792. 171 p. (In Russian)

36. Liechtenhan F.-D. Vol'ter: Fridrikh II ili Petr I [Voltaire: Friedrich II or Peter I]. Vol'ter i Rossiya [Voltaire and Russia]. Moscow: Legacy, 1999, pp. 79-89. (In Russian)

37. Liseytsev D.V. Russko-krymskie otnosheniya v Smutnoe vremya [RussianCrimean relations in the Age of Troubles]. Istoriya Kryma [A History of the Crimea]. Moscow: Kuchkovo Field, 2018, vol. 1, pp. 422-425. (In Russian)

38. Lopatin V.S. Novoe o planakh G.A. Potemkina po prisoedineniyu Kryma k Rossii [New data on G.A. Potemkin's plans for the accession of the Crimea to Russia]. Moskva Krym [Moscow - Crimea]. 2000, no. 2, pp. 88-107. (In Russian)

39. Lopatin V.S. Povest' o Potemkine, knyaze Tavricheskom [A Tale of Potemkin, the Prince of Taurida]. Moscow: "Academic Project", 2018. 537 p. (In Russian)

40. Manstein Ch.H. von. Contemporary Memoires of Russia, from the Year 1727 to 1744. London: Longman, Brown, Green, and Longmans, 1856. $416 \mathrm{p}$.

41. Medvedeva I. Tavrida: istoricheskie ocherki i rasskazy [Taurida: Historical Essays and Stories]. Leningrad: Lenizdat, 1956. 440 p. (In Russian)

42. Mémoire extrait du journal d'un voyage fait, au printemps de 1784, dans la partie méridionale de la Russie. Voyages historiques et géographiques dans les pays situés entre la Mer Noire et la Mer Caspienne. Paris: Deterville, 1798, pt. 3, pp. 1-96. (In French)

43. Montesquieu (Ch.) de. The Spirit of Laws. New York: Colonial Press, 1899, vol. 1. $402 \mathrm{p}$.

44. Myshlaevskiy A.Z. Voyna s Turtsiey 1711 goda (Prutskaya operatsiya): materialy, izvlechennye iz arkhivov [The War with Turkey of 1711 (Prut Operation): The Materials Taken from Archives]. St. Petersburg: Military Typography, 1898. 359 p. (In Russian)

45. Nelipovich S.G. Soyuz dvuglavykh orlov: russko-avstriyskiy voennyy al'yans vtoroy chetverti XVIII v. [A Union of Two-headed Eagles: Russian-Austrian Military Alliance in the second quarter of eighteenth century]. Moscow: Quadriga; Joint Editorial Office of the Ministry of Internal Affairs of Russia, 2010. 408 p. (In Russian)

46. Neumann I.B. Uses of the Other: "The East" in European Identity Formation. Minneapolis: University of Minnesota Press, 1999. 281 p.

47. Novaya imperskaya istoriya Severnoy Evrazii [A New Imperial History of Northern Eurasia]. Kazan: Ab Imperio, 2017, vol. 2. 630 p. (In Russian) 
48. Oreshkova S.F. Krymskoe khanstvo v 70-e gody XVIII v. [The Crimean Khanate in the 1770s]. Voprosy istorii [Issues of History]. 2008, no 7, pp. 121-127. (In Russian)

49. Oreshkova S.F. Osmanskaya imperiya: ocherki istorii [The Ottoman Empire: Essays in Its History]. Moscow: "Frontiers XXI", 2018. 587 p. (In Russian)

50. Ovchinnikov V.D. Bor'ba za Krym. XVIII vek. Istoriko-dokumental'noe issledovanie [The Struggle for the Crimea, the eighteenth century: An Historical and Documental Research]. Moscow: "Russian World", 2015. 320 p. (In Russian)

51. Pamyatniki diplomaticheskikh snosheniy s Rimskoy imperiey [The Monuments of Diplomatic Relations with the Roman Empire]. St. Petersburg: Printing House of the Second Section of His Imperial Majesty's Own Chancellery, 1852, vol. 2. 1542 col.; 1868, vol. 9.1228 col. (In Russian)

52. Perry J. The State of Russia, Under the Present Czar. London: Benjamin Tooke, 1716. $280 \mathrm{p}$.

53. Pis'ma i bumagi imperatora Petra Velikogo, Tom 1: 1688-1701 [Emperor Peter the Great's Correspondence and Papers, Vol. 1: 1688-1701]. St. Petersburg: State Typography, 1887.888 p. (In Russian)

54. Polnoe sobranie zakonov Rossiyskoy imperii [Complete Collection of Laws of the Russian Empire]. St. Petersburg: Printing House of the Second Department of His Imperial Majesty's Own Chancellery, 1830, vol. 21. 1083 p. (In Russian)

55. Problemy integratsii Kryma v sostav Rossii, 1783-1825 [The Aspects of the Crimea's Integration into Russia, 1783-1825]. Sevastopol: Albatross, 2017. 424 p. (In Russian)

56. Przyłecki S. Pamiętniki o Koniecpolskich. Przyczynek do dziejów polskich XVII. wieku [The Memoires on the Koniecpolskis. The Reason of Polish Affaires in the seventeenth century]. Lwów: Typography of Piotr Piller, 1842. 452 p. (In Polish)

57. Rakhimzyanov B.R. Moskva i tatarskiy mir: sotrudnichestvo i protivostoyanie $v$ epokhu peremen, $X V-X V I v v$. [Moscow and the Tatar World: Cooperation and Confrontation in the Age of Changes, fifteenth to sixteenth century]. St. Petersburg: Eurasia, 2017. 396 p. (In Russian)

58. Rousseau J.J. The Social Contract. New York: Carlton House, [n. d.]. 271 p.

59. Russkoe gosudarstvo v polovine XVII veka. Rukopis' vremen tsarya Alekseya Mikhaylovicha [The Russian State in the mid-seventeenth century: A Manuscript from the Age of Czar Alexis Mikhaylovich]. Moscow: Printing House of Aleksandr Semena, 1860, vol. 2. 392 p. (In Russian)

60. Skazanie svyashchennika Yakova [The Tale of Priest Yakov]. Zapiski Odesskogo obshchestva istorii i drevnostey [Proceedings of the Odessa Society of History and Antiquities]. 1848, vol. 2, pp. 685-692. (In Russian)

61. Slavyanskie narody Yugo-Vostochnoy Evropy i Rossiya v XVIII veke [Slavic Peoples of South-East Europe and Russia in the Eighteenth Century]. Moscow: Nauka, 2003. 315 p. (In Russian)

62. Smoliy V., Kul'chyts'kyy S., and Yakubova L. Donbas i Krim v ekonomichnomu, suspil'no-politichnomu ta etnokul'turnomu prostori Ukraïni: istorichnyy dosvid, moderni vyklyki, perspektivi [The Donbass and Crimea in Economic, Social-political, and Ethnocultural Space of Ukraine: Historical Experience, Modern Challenges, and Perspectives]. Kyiv: Institute of History of Ukraine of the National Academy of Sciences of Ukraine, 2016. 616 p. (In Ukrainian)

63. Solov'ev S.M. Istoriya Rossii s drevneyshikh vremen [A History of Russia from the Most Ancient Times]. Moscow: Socio-economic Literature Publishing House, 1960, book 3, vol. 5-6. 814 p.; 1962, book 7, vol. 13-14. 725 p. (In Russian)

64. Stroev A. "Te, kto popravlyaet Fortunu”. Avantyuristy Prosveshcheniya [The "Correctors of Fortune": Adventurers of the Enlightenment]. Moscow: New Literary Review, 1998. 398 p. (In Russian) 
65. Taki V. Tsar' $i$ sultan. Osmanskaya imperiya glazami rossiyan [Czar and Sultan: The Ottoman Empire as Viewed by the Russians]. Moscow: New Literary Review, 2017. 320 p. (In Russian)

66. The Works of the Rev. Jonathan Swift, D.D., Dean of St. Patrick's, Dublin. London: J. Johnson, etc., 1801, vol. 7. 436 p.

67. Ul'yanov N.I. Kompleks Filofeya [The Filofei Complex]. Ul'yanov N.I. Istoricheskiy opyt Rossii i ukrainskiy separatizm [Ul'yanov N.I. Russia's Historical Experience and Ukrainian Separatism]. St. Petersburg: Russian Island, 2015, pp. 76-96. (In Russian)

68. Urkunden durch welche die im dritten Theil des Magazins gelieferte Lebensbeschreibung des Generalfeldmarschalls Grafen von Münnich ergänzet und bestätiget wird. Magazin für die neue Historie und Geographie. Halle: Johann Jacob Curts Witwe, 1782, vol. 16, pp. 401-486. (In German)

69. Vasil'ev D.V. Rozhdenie imperii. Yugo-vostok Rossii: XVIII - pervaya polovina $X I X v$. [The Birth of the Empire: The South-East of Russia, the eighteenth to the first half of nineteenth century]. St. Petersburg: Dmitriy Bulanin, 2020. 608 p. (In Russian)

70. Vernadsky G.V. Zapiski o neobkhodimosti prisoedineniya Kryma k Rossii (iz Tavel'skogo arkhiva V.S. Popova) [Memoires on the need of accession of the Crimea to Russia (from V.S. Popov's Tavel' Archive)]. Izvestiya Tavricheskoy uchenoy arkhivnoy komissii [Proceedings of the Taurida Scholarly Archival Commission]. 1919, no. 56, pp. 111-126. (In Russian)

71. Vinogradov V.N. Diplomatiya Ekateriny Velikoy [Catherine II's Diplomacy]. Novaya i noveyshaya istoriya [Modern and Contemporary History]. 2001, no. 3, pp. 131-150; no. 4, pp. 124-148; no. 6, pp. 109-136. (In Russian)

72. Voltaire. Evres completes. Paris: Pourrat frères et $C^{\text {ie }}, 1831$, vol. 3. 516 p. (In French)

73. Voltaire. History of Peter the Great, Emperor of Russia. New York: Leavitt \& Allen, 1857, vol. 1.408 p.

74. Vsepoddaneyshie doneseniya gr. Minikha, ch. 1 [Count Münnich's most humble reports, pt. 1]. Sbornik voenno-istoricheskikh materialov [A Collection of Military Historical Materials]. 1897, no. 10, pp. 1-330. (In Russian)

75. Vysochayshie reskripty Ekateriny II i ministerskaya perepiska po delam Kryma. Iz semeynogo arkhiva grafa Viktora Nikiticha Panina, ch. I [The most high rescripts of Catherine II and Ministerial correspondence on the Crimean affairs. From Count Viktor Nikitich Panin's family archive, pt. 1]. Chteniya $v$ Imperatorskom obshchestve istorii i drevnostey rossiyskikh pri Moskovskom universitete [Readings at the Imperial Society of Russian History and Antiquities at Moscow University]. 1871, vol. 4, sect. 2, pp. 1-168. (In Russian)

76. Williams B.G. The Crimean Tatars: The Diaspora Experience and the Forging of a Nation. Leiden; Boston; Köln: Brill, 2001. 488 p.

77. Zapadnye okrainy Rossiyskoy imperii [The Russian Empire's Western Frontiers]. Moscow: New Literary Review, 2007. 608 p. (In Russian)

78. Zapiski fel'dmarshala grafa Minikha [Memoirs of the Field Marshal Count Münnich]. Moscow: State Public Historical Library of Russia, 2017. 384 p. (In Russian)

79. Zhurnaly Krymskikh pokhodov rossiyskoy armii 1735-1738 gg. Sbornik dokumentov [Journals of the Russian Army's Crimean Campaigns of 1735-1738: Collected Documents]. Rostov-on-Don: Publishing House of the Southern Scientific Center of the Russian Academy of Sciences, 2017. 484 p. (In Russian)

80. Zorin A. By Fables Alone: Literature and State Ideology in Late-Eighteenth - Early-Nineteenth-Century Russia. Boston: Academic Studies Press, 2014. 406 p. 
About the author: Nikita I. Khrapunov - Cand. Sci. (History), Leading Researcher of the Research Centre for the History and Archaeology of Crimea, V.I. Vernadsky Crimean Federal University (4, Vernadsky Ave., Simferopol 295007, Republic of Crimea, Russian Federation); ORCID: 0000-0001-6141-9487, ResearcherID: Q-8101-2017. E-mail: khrapunovn@mail.ru

Received September 20, 2021 Accepted for publication December 3, 2021 Published December 29, 2021

\title{
КРЫМСКИЙ ВОПРОС В «ЗАПАДНЫХ» ПРОЕКТАХ, ПОЛИТИЧЕСКИХ ТРАКТАТАХ И ПЕРЕПИСКЕ СЕРЕДИНЫ ХVI В. - 1783 Г.
}

\author{
Н.И. Храпунов \\ Крымский федеральный университет им. В.И. Вернадского \\ Симферополь, Российская Федерация \\ khrapunovn@mail.ru
}

Целью статьи является выявление и изучение разнообразных документов, созданных до 1783 г., в которых предлагалось изменить статус Крыма и присоединить его к России, определение взаимовлияния этих источников, а также общих направлений и принципов обсуждения «крымского вопроса» в отечественной и зарубежной общественной мысли.

Материалом исследования стал обширный комплекс источников, в которых обсуждалось будущее Крыма - политические трактаты, докладные записки, исторические сочинения, переписка, созданные в России и на Западе в XVI-XVIII вв.

В результате исследования впервые в историографии проанализирован весь комплекс документов, свидетельствующих о разнообразных планах по присоединению Крыма к России. Установлено, что «крымский вопрос» на Западе в определённые моменты обсуждался шире, чем в России. Участниками этой «дискуссии» были самые разные лица, включая лидеров обществ мнения - Вольтера, Франческо Альгаротти и других. Продемонстрированы попытки европейских интеллектуалов воздействовать на решения российских властей. Таким образом, присоединение Крыма продукт не только «российского империализма», но в известной степени и европейской общественной мысли. Это решение считалось на Западе вполне допустимым, причём многие рассматривали его в позитивном ключе как для международной обстановки, так и для развития самого региона. Раскрыта динамика аргументации, первоначально использовавшей антимусульманскую риторику, подчёркивавшую экзистенциальное противостояние христианства и ислама и необходимость «вернуть» земли, некогда принадлежавшие Европе. С наступлением эпохи Просвещения возникли рассуждения о цивилизаторской миссии Европы и о торговле как сути прогресса, развитию которой в Причерноморье мешало «косное» исламское общество. В России дискуссия о будущем Крыма активизировалась во 2-й-3-й четвертях XVIII в., когда элиты осознали, что покорение полуострова стало реально возможным.

Ключевые слова: Крым, Россия, Крымское ханство, Османская империя, общественная мысль, проекты 
Для цитирования: Khrapunov N.I. The Crimea Question in "Western" Projects, Political Treatises, and Correspondence from the mid-sixteenth century to 1783 // Золотоордынское обозрение. 2021. Т. 9, № 4. С. 857-877. DOI: 10.22378/2313-6197.2021-9-4. 857-877

Благодарности: Работа выполнена в рамках госзадания Министерства науки и высшего образования РФ № FZEG-2020-0029.

Сведения об авторе: Никита Игоревич Храпунов - кандидат исторических наук, ведущий научный сотрудник Научно-исследовательского центра истории и археологии Крыма, Крымский федеральный университет им. В.И. Вернадского (295007, пр. Вернадского, 4, Симферополь, Республика Крым, Российская Федерация); ORCID: 00000001-6141-9487, ResearcherID: Q-8101-2017. E-mail: khrapunovn@mail.ru

Поступила 20.09.2021 Принята к публикащии 03.12.2021

Опубликована 29.12.2021 